\title{
Statyba
}

\section{ELASTIC-PLASTIC ANALYSIS OF BISTEEL I-SECTION BEAMS}

\section{A. Jaras \& R. Kačianauskas}

To cite this article: A. Jaras \& R. Kačianauskas (2001) ELASTIC-PLASTIC ANALYSIS OF

BISTEEL I-SECTION BEAMS, Statyba, 7:2, 122-130, DOI: 10.1080/13921525.2001.10531713

To link to this article: https://doi.org/10.1080/13921525.2001.10531713

册 Published online: 30 Jul 2012.

Submit your article to this journal 저

山 Article views: 96

7 Citing articles: 1 View citing articles 


\section{BIMETALIŲ DVITÉJŲ SIJŲ BŪVIO ANALIZE், IVERTINANT PLASTINIŲ DEFORMACIJŲ ITAKĄ}

\section{A. Jaras, R. Kačianauskas}

Vilniaus Gedimino technikos universitetas

\section{Ivadas}

Šiuo metu pasaulyje ir Lietuvoje vyrauja pastatų iš metalo konstrukciju statybos tendencijos [1,2]. Lenkiamieji šių konstrukcijų elementai naudojami tiek formuojant naujas denginio ir perdangos konstrukcijas, tiek jas rekonstruojant. Daugeliu atveju lenkiamosios konstrukcijos projektuojamos naudojant suvirinto arba valcuoto dvitèjo skerspjūvio elementus, pagamintus iš plieno, numatyto šalies gamintojos standarte. Tačiau dẻl netolygaus irą̌ž ir ịtempimų pasiskirstymo sijoje plieno laikomoji galia visiškai išnaudojama tik juostose ties viduriniaja sijos dalimi, o sieneleje ir skerspjūviuose, artimuose atramoms, itempimai daug mažesni. Siekiant racionalesnio metalo panaudojimo yra sukurti keli šios problemos sprendimo būdai: formuoti kintamojo skerspjūvio (tarp jų su antdèklais) sijas; komponuoti bimetales dvitèjo skerspjūvio sijas, suvirintas iš skirtingo stiprumo plienų.

Ivairūs tyrimai [3-11] rodo, kad bimetalès sijos gali būti daug ekonomiškesnès už sijas, pagamintas iš vienodo stiprumo plieno. Dažniausiai pasitaiko šie dvitèju bimetalių sijų iš skirtingo stiprumo plienų tipai:

1. Bimetalès suvirintos dvitèjès sijos su padidinto stiprumo plieno intarpais labiausiai lenkiamoje sijos dalyje [11]. Šiuo atveju ivertinamas netolygus irąžu pasiskirstymas sijoje.

2. Bimetalès suvirintos dvitèjès sijos, kuriu sienele ir juostos yra iš skirtingo stiprumo plieno [7]. Šiuo atveju ivertinamas netolygus ittempimu pasiskirstymas sijos aukštyje.

3. Bimetalès suvirintos dvitẻjès sijos su padidinto stiprumo plieno intarpais $[6,9]$ bei dvitejejs sijos su padidinto stiprumo plieno antdèklais $[4,5]$ labiausiai itemptose sijos juostų srityse. Šiuo atveju ivertinamas netolygus ịrąžų bei itempimų pasiskirstymas.
Tyrimai [11] rodo, kad pirmuoju atveju, kai labiausiai lenkiamose sijos srityse visas skerspjūvis sukomponuotas iš padidinto stiprumo plieno, gaunamas tik dalinis ekonominis efektas, nes lieka neišnaudota plieno laikomoji galia sieneleje. Kitais atvejais, ypač naudojant juostų intarpus arba antdeklus, metalas sijoje panaudojamas daug efektyviau.

Darbe nagrinejjamos bimetalès suvirintos dvitèjo skerspjūvio tampriai plastinès dviatramès sijos su padidinto stiprumo plieno intarpais labiausiai itemptose juostụ dalyse. Siekiant ịvertinti jụ būvi, gautos analizinès lenkimo momentų skaičiavimo išraiškos visiems plastinių deformacijų atsivèrimo ir plitimo bimetaliame dvitèjame skerspjūvyje atvejams bei analizinè sijos vidurio ¡llinkio skaičiavimo išraiška. Ištirtas plastinių deformacijų pasiskirstymas, jų gylio itaka sijų stiprumui ir standumui bei juostu intarpu komponavimui. Nagrinèti ¿vvairūs sijos ir juostų intarpu plieno stiprumo rodiklių deriniai. Analizinių išraišku patikrai atliktas skaitinis eksperimentas naudojant BEM programini paketą ANSYS. Bimetalè sija diskretizuota trimačiais dešimties mazgu tetraedro formos SOLID-92 tipo baigtiniais elementais. Palyginti skaitinio eksperimento ir analiziniai rezultatai.

\section{Tyrimo objektas}

Nagrinèjama dviatramè, dvitèjè sija, kurios labiausiai ịtemptose juostų srityse ikomponuoti padidinto stiprumo (mažai legiruoto) plieno intarpai (1 pav. a). Sija apkrauta statine, tolygiai išskirstyta per visą sijos ilgi apkrova $p$ ( 1 pav. b).

Nagrinejjamas skerspjūvis yra simetrinis, dvitejjis, suvirintas iš valcuotojo plieno lakštų. Kadangi juostų skerspjüvio kitimas bimetalèse sijose nèra efektyvus [9], laikoma, kad skerspjūvio matmenys visu sijos ilgiu yra pastovũs ir proporcingi dvitèju sortimento matmenims. 


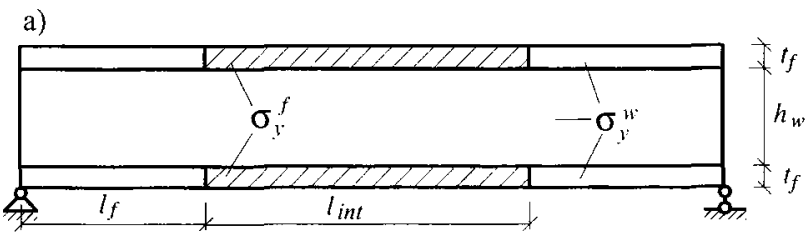

b)

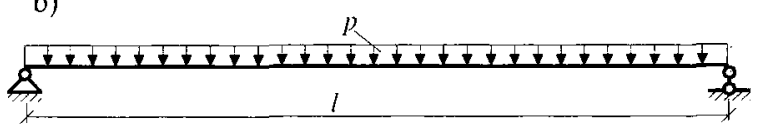

1 pav. a) Bimetalè dvitèjè sija; b) skaičiuojamoji schema

Fig 1. a) I section bisteel beam; b) design scheme

Taip išlaikoma sąlyga, kad vietinis sienelès stabilumas būtų užtikrintas ir skersinès bei išilginés standumo briaunos sienelèje nèra reikalingos.

Esant fiksuotam sijos ilgiui, uždavinyje kinta sijos sienelés ir juostų intarpo plieno stiprumo rodikliai $\sigma_{y}^{w}$ ir $\sigma_{y}^{f}$ (1 pav. a); skerspjūvio matmenys $b_{f}, t_{f}, h_{w}, t_{w}$ (2 pav. a); plastinių zonų gylis a (3 pav.); padidinto stiprumo plieno intarpu sijos juostose ilgis $l_{\text {int }}$ ( 1 pav. a).

Tamprumo modulis $E$ visiems nagrinejjamiems sijos sienelès ir intarpu plienams yra vienodas.

\section{Teorinès prielaidos, uždavinio formulavimas}

Straipsnyje apsiribojama geometriškai tiesine, mažų deformacijų plastiškumo teorija. Imamas idealus tampriai plastinis medžiagos deformavimosi modelis.

Plokščiuju pjūvių hipotezé galioja. Laikoma, kad ¡tempimu būvis yra vienašis ir skersiniu jègų įtaka sijos stiprumui ir standumui nera vertinama.
Bendruoju atveju yra galimi tokie bimetalès sijos deformavimo tarpsniai:

1. Sija deformuojama tampriai (2 pav. b).

Kadangi šiuo atveju toli gražu neišnaudojama padidinto stiprumo plieno laikomoji galia, šis atvejis nèra nagrinèjamas.

2. Leidžiamas dalinis plastiniu deformaciju plitimas sijoje.

Sijose, pagamintose tik iš vienos rūšies konstrukcinio plieno, plastiniu deformaciju atsivèrimo ir plitimo scenarijus deformavimo metu yra vienintelis ir vienareikšmis. Pirmiausia plastinès deformacijos atsiranda kraštiniuose, labiausiai itemptuose skerspjūvio sluoksniuose ir, didèjant apkrovai, skverbiasi i gilesnius.

Bimetales sijos atveju plastinių deformacijų atsivèrimas dvitèjame skerspjūvyje priklauso nuo sijos sienelès ir juostų plienų stiprumo rodiklių santykio. Kai juostụ intarpų plieno takumo riba daug didesnè už sienelès (t. y. $\sigma_{y}^{f}>\frac{h}{h_{w}} \sigma_{y}^{w}$ ), plastinio deformavimo metu plienas pirmiausia pradeda tekèti sienelèje ( 2 pav. c). Priešingu atveju (t. y. $\sigma_{y}^{f}<\frac{h}{h_{w}} \sigma_{y}^{w}$ ) plienas pirmiau pradeda tekèti juostose ( 2 pav. d). Kitas plastinio deformavimo etapas parodytas 2 pav. e. Plastinèms deformacijoms plintant toliau, galiausiai prasideda racionaliausias bimetalès sijos skerspjūvio darbo etapas, kai juostos visiškai teka, o sieneleje pasireiškia ribotos plastinès deformacijos (2 pav. $\mathrm{f}$ ).

Šie tampriai plastinio deformavimo modeliai yra reglamentuoti ir šiuo metu galiojančiose Statybos nor- a)

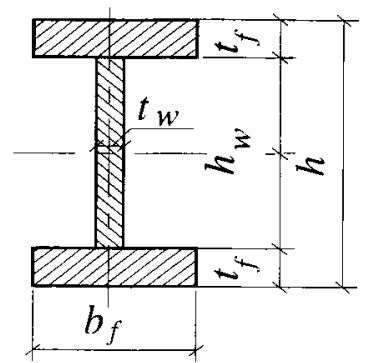

b)

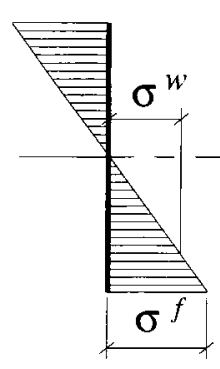

c)

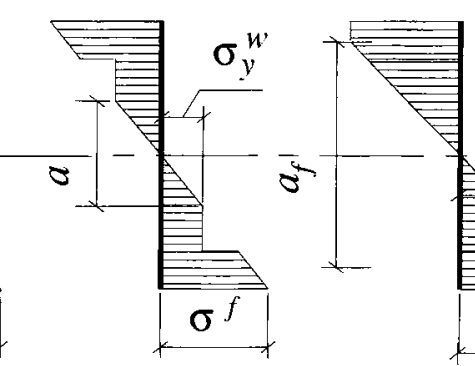

d)

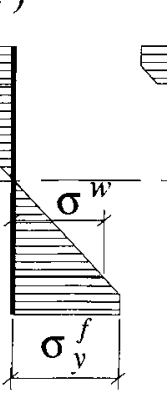

e)

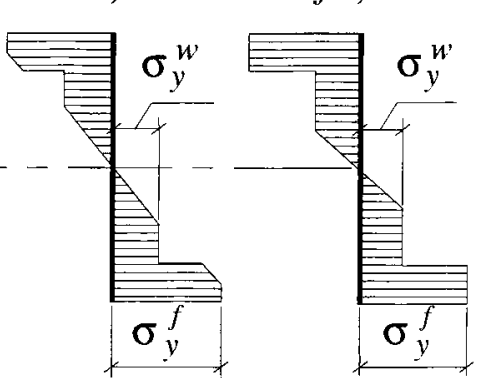

2 pav. Galimi plastinių deformaciju atsivèrimo ir plitimo bimetalès dvitèjẻs sijos skerspjūvyje atvejai: b) tamprus darbas; c) plastinès deformacijos tik sienelèje; d) plastinès deformacijos tik juostose; e) ribotos plastinès deformacijos ir juostose, ir sieneleje; f) ribotos plastinès deformacijos sienelèje, kai juostos visiškai teka

Fig 2. The cases of appearing and penetration of plastic strain in I-section bisteel beams: b) elastic stage; c) plastic strain in web; d) plastic strain in flanges; e) limited plastic strain both in flanges and in web; f) limited plastic strain in web, and the full plasticity of flanges 
mose ir taisyklèse (SNirT): skaičiuojant plienines konstrukcijas, ịvertinant fizinius netiesiškumus, leidžiama taikyti mažų plastinių deformacijų teoriją esant paprastam apkrovimui [8]. Šios normos rekomenduoja, skaičiuojant tampriai plastinių konstrukcijų stipruma, atitinkamoms konstrukcijų grupèms taikyti du plastinių deformaciju atskaitos kriterijus:

- maksimalių țtempimų (kai leidžiamos plastinès deformacijos tik sieneléje, 2 pav. c);

- ribotú plastiniu deformaciju (kai leidžiamos plastinès deformacijos juostose ir sienelèje 2 pav. f). Pastaruoju atveju pasiekiamas didesnis konstrukcinių medžiagų stiprumo rodiklių išnaudojimas, kuris bimetalès sijos atveju yra ypač efektyvus.

Praktiškai yra galimi visi keturi plastinių deformacijų atsivèrimo ir plitimo atvejai ( 2 pav. c-f). Todèl, atliekant bimetaliu siju ittempimų-deformaciju būvio analizę, reikalingos analizinès priklausomybès sijos stiprumui ir standumui skaičiuoti kiekvienu tampriai plastinio deformavimo etapu ( 2 pav. c-f).

\section{Analizinis plastinių deformacijų ivertinimas}

Skaičiuojant sijas, ju laikomają galią apibūdina du rodikliai: ribinis lenkimo momentas $M$ ir maksimalus ilinkis $u$. Tampriai plastinio deformavimo metu abu minéti rodikliai $(M, u)$ priklauso nuo plastiniu zonu pasiskirstymo.

Analizinèms lenkimo momentų formulèms gauti kiekvienam plastinio deformavimo atvejui yra užrašomos integralinès lenkimo momentụ išraiškos $[12,13]$ :

$$
M=\int_{A} \sigma y d A .
$$

Bendruoju atveju šis integralas susideda iš narių, Łvertinančiu tampriąsias ir plastines sijos skerspjūvio sritis. Tuo atveju, kai plastinès deformacijos atsiveria tik sienelèje ( 2 pav. c) integralinę lenkimo momento išraišką sudaro trys integralai, išreiškiantys tampriają, plastinę sieneles bei tampriąsias juostų sritis:

$$
\begin{gathered}
M_{c}=2 \int_{0}^{a / 2} \sigma^{w} y d y t_{w}+2 \int_{a / 2}^{h_{w} / 2} \sigma_{y}^{w} y d y t_{w}+ \\
2 \int_{h_{w^{\prime}} / 2}^{\left(h_{w} / 2\right)+t_{f}} \sigma^{f} y d y b_{f} .
\end{gathered}
$$

Atsižvelgiant $\mathfrak{i}$ tiesini itempimų kitimo dèsni, ittempimus juostose ir tampriojoje sienelès dalyje galima išreikšti per sienelès plieno stiprumo rodikli $\sigma_{y}^{w}$. Tada išraiška (2) atrodys taip:

$$
\begin{aligned}
M_{c}= & 2 \int_{0}^{a / 2} \sigma_{y}^{w} \frac{y}{a / 2} y d y t_{w}+2 \int_{a / 2}^{h_{w} / 2} \sigma_{y}^{w} y d y t_{w}+ \\
& 2 \int_{h_{w} / 2}^{\left(h_{w} / 2\right)+t_{f}} \sigma_{y}^{w} \frac{y}{a / 2} y d y b_{f} .
\end{aligned}
$$

Ivertinant tampriąsias bei plastines dvitejo skerspjūvio sritis, užrašomos integralinès lenkimo momentų išraiškos ir kitiems plastinio deformavimo atvejams (2 pav. d-f):

$$
\begin{aligned}
& M_{d}=2 \int_{0}^{h_{w} / 2} \sigma_{y}^{f} \frac{y}{a_{f} / 2} y d y t_{w}+ \\
& 2 \int_{h_{w} / 2}^{a_{f} / 2} \sigma_{y}^{f} \frac{y}{a_{f} / 2} y d y b_{f}+2 \int_{a_{f} / 2}^{\left(h_{w} / 2\right)+t_{f}} \sigma_{y}^{f} y d y b_{f},
\end{aligned}
$$

$$
\begin{aligned}
M_{e}= & 2 \int_{0}^{a / 2} \sigma_{y}^{w} \frac{y}{a / 2} \mathrm{y} d y t_{w}+2 \int_{a / 2}^{h_{w} / 2} \sigma_{\mathrm{y}}^{\mathrm{w}} y d y t_{w}+ \\
& 2 \int_{h_{w} / 2}^{a_{f} / 2} \sigma_{y}^{f} \frac{y}{a_{f} / 2} y d y b_{f}+2 \int_{a_{f} / 2}^{\left(h_{w} / 2\right)+t_{f}} \sigma_{y}^{f} y d y b_{f},
\end{aligned}
$$

$$
\begin{gathered}
M_{f}=2 \int_{0}^{a / 2} \sigma_{y}^{w} \frac{y}{a / 2} y d y t_{w}+2 \int_{a / 2}^{h_{w} / 2} \sigma_{y}^{w} y d y \mathrm{t}_{w}+ \\
2 \int_{h_{w} / 2}^{\left(h_{w} / 2\right)+t_{f}} \sigma_{y}^{f} y d y b_{f} .
\end{gathered}
$$

Integralines išraiškas 3-6 suintegravus kompiuterine matematine sistema MATHEMATICA [14], yra gautos analizinès sijos lenkimo momentų skaičiavimo formulès kiekvienu bimetales dvitejès sijos plastinio deformavimo atveju ( 2 pav. c-f):

$$
\begin{gathered}
M_{c}=\sigma_{y}^{w} t_{w} \frac{a^{2}}{6}+\sigma_{y}^{w} t_{w}\left(\frac{h_{w}^{2}}{4}-\frac{a^{2}}{4}\right)+ \\
\sigma_{y}^{w} \frac{4 b_{f}}{3 a}\left(\left(\frac{h_{w}}{2}+t_{f}\right)^{3}-\frac{h_{w}^{3}}{8}\right),
\end{gathered}
$$




$$
\begin{aligned}
& M_{d}=\sigma_{y}^{f} t_{w} \frac{h_{w}^{3}}{6 a_{f}}+\sigma_{y}^{f} \frac{b_{f}}{a_{f}}\left(\frac{a_{f}^{3}}{6}-\frac{h_{w}^{3}}{6}\right)+ \\
& \sigma_{y}^{f} b_{f}\left(\frac{h_{w}^{2}}{4}+h_{w} t_{f}+t_{f}^{2}-\frac{a_{f}^{2}}{4}\right), \\
& M_{e}=\sigma_{y}^{w} t_{w} \frac{a^{2}}{6}+\sigma_{y}^{w} t_{w}\left(\frac{h_{w}^{2}}{4}-\frac{a^{2}}{4}\right)+\sigma_{y}^{f} \frac{b_{f}}{a_{f}} \times \\
& \left(\frac{a_{f}^{3}}{6}-\frac{h_{w}^{3}}{6}\right)+\sigma_{y}^{f} b_{f}\left(\frac{h_{w}^{2}}{4}+h_{w} t_{f}+t_{f}^{2}-\frac{a_{f}^{2}}{4}\right) \text {, } \\
& M_{f}=\sigma_{y}^{w} t_{w} \frac{a^{2}}{6}+\sigma_{y}^{w} t_{w}\left(\frac{h_{w}^{2}}{4}-\frac{a^{2}}{4}\right)+ \\
& \sigma_{y}^{f} b_{f}\left(t_{f} h_{w}+t_{f}^{2}\right),
\end{aligned}
$$

čia $t_{w}, h_{w}, b_{f},_{f}-$ dvitejjo skerspjūvio matmenys; $\sigma_{y}^{w}, \sigma_{y}^{f}-$ sijos ir juostų plienų stiprumo rodikliai, atitinkantys ju takumo ribas.

Plastinių deformaciju gylis sienelèje bei juostose yra išreiškiamas per sienelès tampriosios zonos aukštį:

$$
\begin{gathered}
a=h_{w} c, \\
a_{f}=a \sigma_{y}^{f} / \sigma_{y}^{w},
\end{gathered}
$$

čia $c$ - koeficientas, nusakantis tampriosios zonos aukšti parenkamas kiekvienai formulei atskirai pagal jos galiojimo ribas.

Gautos išraiškos (7-10) tinka visoms bimetalèms dvitëjèms sijoms nepriklausomai nuo jų apkrovimo ir atrèmimo sąlygų. Jomis, imant ribotas plastines deformacijas, išreikštas per sienelès (juostu) tampriosios zonos aukšti $a\left(a_{f}\right)$, galima apskaičiuoti lenkimo momentą $M$ nagrinejjamame bimetalès dvitẻjès sijos skerspjūvyje. Tada, atsižvelgiant i sijos apkrovimo ir parėmimo sąlygas, pagal žinomas medžiagu mechanikos išraiškas galima nustatyti ir ši lenkimo momentą atitinkančią apkrovą nagrinejamo tipo sijoje.

Plastinèms deformacijoms plintant sijos skerspjūvyje susidaro plastinès zonos ir sijos ilgyje. Tai tiesiogiai lemia tyrimo metu nustatomą sijos standumo rodiklị - ilinki $(u)$ ir apibréžia juostų intarpu ilgi $\left(l_{\text {int }}\right)$. Dèl skirtingų sijos ir juostų intarpu plienu stiprumo rodiklių plastinių zonų išplitimo ribos bimetalès sijos juostose ir sienelèje yra skirtingos (3 pav.).

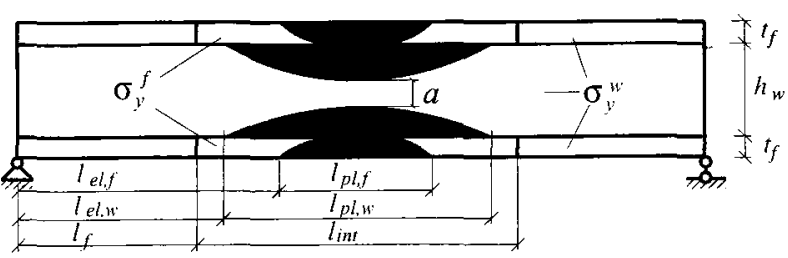

3 pav. Plastiniu zonu bimetalèje sijoje vaizdas

Fig 3. The distribution of plastic strain of bisteel beam

Kraštiniai grynai tampriai dirbantys sijos juostu ir sienelès skerspjūviai nustatomi iš lenkimo momento pjūvyje, atstumu $z$ nutolusiame nuo atramos ir tampraus lenkimo momento lygybès:

$$
\frac{p l z}{2}-\frac{p z^{2}}{2}=M_{e l}
$$

Gautas kvadratinès lygties sprendinys rodo kraštines visiškai tampriai dirbančiu sijos juostu ir sienelès skerspjūvių padètis (3 pav.):

$$
\begin{aligned}
& l_{e l, f}=\frac{l}{2} \pm \frac{1}{2 p} \sqrt{(p l)^{2}-8 p M_{e l}^{f}} \\
& l_{e l, w}=\frac{l}{2} \pm \frac{1}{2 p} \sqrt{(p l)^{2}-8 p M_{e l}^{w}}
\end{aligned}
$$

čia $M_{e l}^{f}=\sigma_{y}^{f} \cdot W_{e l}$ ir $M_{e l}^{w}=\sigma_{y}^{w} \cdot \frac{I}{h_{w} / 2}$ - lenkimo momentai iki atsirandant plastinèms deformacijoms atitinkamai juostose ir sienelèje; $p=\frac{8 M}{l^{2}}$ - veikianti išskirstytoji apkrova; $W_{e l}-$ skerspjūvio tamprus atsparumo momentas; $I$ - skerspjūvio inercijos momentas.

Tada plastiniu zonu sieneleje ir juostose ilgiai bus:

$$
\begin{aligned}
& l_{p l, f}=l-2 l_{e l, f}=\frac{1}{p} \sqrt{(p l)^{2}-8 p M_{e l}^{f}}, \\
& l_{p l, w}=l-2 l_{p l, w}=\frac{1}{p} \sqrt{(p l)^{2}-8 p M_{e l}^{w}} .
\end{aligned}
$$

Tiriant buvo laikomasi sąlygos, kad plastinès deformacijos sijos juostu ir ju intarpu suvirinimo siūlèse nèra leistinos ( 3 pav.). Tuo atveju juostų intarpu ilgis imamas pagal sijos plastinès zonos kraštus (4 pav.) ir nustatomas pagal išraišką:

$$
l_{\text {int }}=l-2 l_{f}=\frac{1}{p} \sqrt{(p l)^{2}-8 p M_{e l}},
$$

čia $M_{e l}=\sigma_{y}^{w} \cdot W_{e l}-$ tamprus lenkimo momentas. 


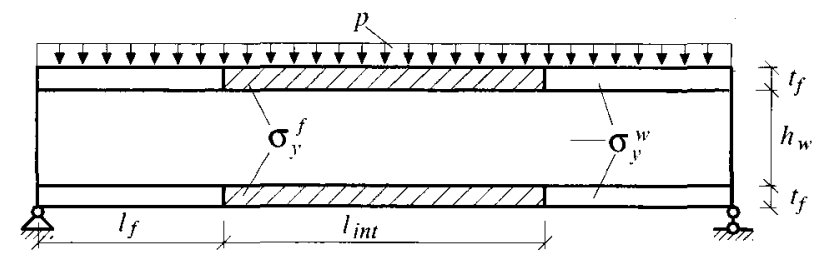

4 pav. Bimetalè dvitèjè sija

Fig 4. I-section bisteel beam

Ivertinant gautas plastiniu zonų sijos ilgyje ribas, užrašoma integralinè sijos vidurio ilinkio skaičiavimo išraiška:

$$
u=2 \int_{0}^{l_{e l}} m d \alpha+2 \int_{l_{e l}}^{l / 2} m d \alpha
$$

İrašius tampriam bei tampriai plastiniam sijos ruožams atitinkamus narius [13] gaunama:

$$
u=2 \int_{0}^{l_{e l, w}} \frac{1}{2} \frac{M}{E I} z d z+2 \int_{l_{e l, w}}^{l / 2} \frac{1}{2} \frac{\sqrt{n} \frac{M_{e l}}{E I}}{\sqrt{\mathrm{m}-\frac{M}{M_{e l}}}} \mathrm{z} d z
$$

Išraišką suintegravus kompiuterinès matematikos sistema MATHEMATICA [14], gauta analizinè bimetalès dvitèjès sijos vidurio įlinkio skaičiavimo išraiška, kurios du pirmieji nariai ivertina tampriujų, o trečiasis - tampriai plastinio sijos ruožų darbą:

$$
u=\frac{l p l_{e l}^{3}}{6 E I}-\frac{p l_{e l}^{4}}{8 E I}+\frac{\sqrt{2 n M_{e l}^{3}}}{E I \sqrt{p}}\left[u_{1}+u_{2}\right],
$$

čia

$$
\begin{aligned}
& u_{1}=\sqrt{\frac{2 M_{e l} m}{p}-\frac{l^{2}}{4}-\sqrt{\left(l_{e l}-\frac{l}{2}\right)^{2}+\frac{2 M_{e l} m}{p}-\frac{l^{2}}{4}}}, \\
& u_{2}=\frac{l}{2} \ln \frac{\sqrt{\frac{2 M_{e l} m}{p}-\frac{l^{2}}{4}}}{\left|l_{e l}-\frac{l}{2}+\sqrt{\left(l_{e l}-\frac{l}{2}\right)^{2}+\frac{2 M_{e l} m}{p}-\frac{l^{2}}{4}}\right|},
\end{aligned}
$$

$n=m-1=\frac{M_{f p}}{M_{e l}}-1 ; M_{f p}-$ visiškai plastinis lenkimo momentas; $M_{e l}$ - tamprus lenkimo momentas; $p$ - apkrova, atitinkanti lenkimo momentą $(7-10)$.

\section{Plastiniu deformaciju tyrimas}

Gautos priklausomybès $(7-10,21)$ buvo pritaikytos tiriant plastinių deformaciju pasiskirstyma, jų itaką stiprumui ir standumui bei juostų intarpu komponavimui dviatramès sijos, apkrautos išskirstytaja apkrova, atveju. Sukurta kompiuteriné programa BTsija (FORTRAN), kuri leidžia atlikti bimetalių dvitejų sijų būvio analizę visais plastinio deformavimo etapais. Apdorojus gautus rezultatus, jie pateikiami santykine forma [15].

Atlikus analizinius skaičiavimus pasitvirtino inžinerinejje praktikoje žinoma tiesa, kad sijose, kuriu juostos ir sienelè yra iš skirtingo stiprumo plieno, plastiniu zonų išplitimo ribos yra skirtingos (3 pav.). Juostose su padidinto stiprumo plieno intarpais plastinès deformacijos išplinta mažiau negu sienelèje. Šis skirtumas yra proporcingas plienų stiprumo rodiklių santykiui. Esant vienodam plastinių deformaciju vidurinio sijos pjūvio juostose gyliui, plastinių zonų ribos juostose taip pat priklauso nuo intarpo plieno stiprumo rodiklių: kuo $\sigma_{y}^{f}$ didesnis, tuo plastinių zonu juostose ilgis $l_{p l, f}$ mažesnis (5 pav.).

Priklausomybė tarp plastinių deformacijų išplitimo sienelès ilgyje ir gylyje (6 pav.) savo pobūdžiu atspindi tris bimetalès sijos plastinio deformavimo etapus (2 pav. c, e ir f).

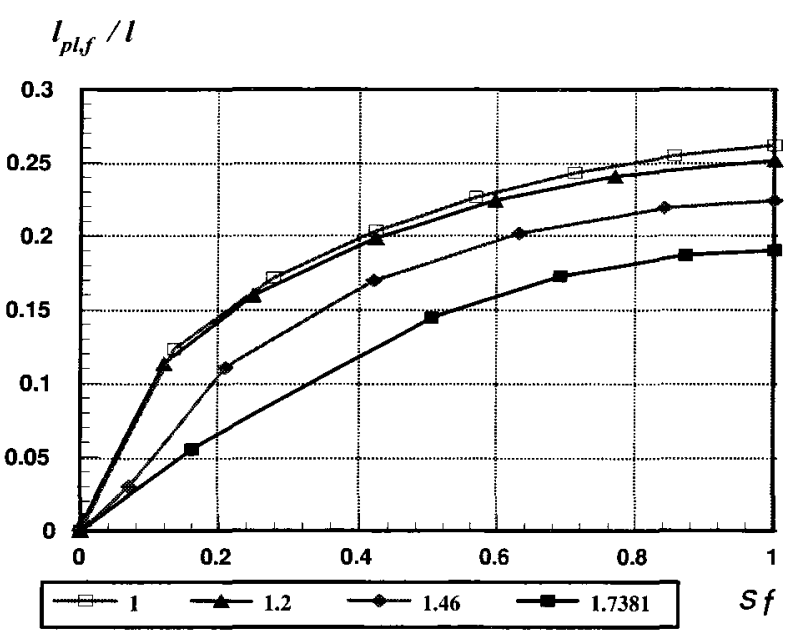

5 pav. Priklausomybès tarp santykinio plastinių deformaciju išplitimo sijos juostose ilgio $l_{p l, f} / l$ ir santykinio maksimaliu plastiniu deformaciju juostose gylio $\mathrm{s}_{f}=\left(h-a_{f}\right) / 2 t_{f}$, esant skirtingiems juostu intarpu ir sijos plieno stiprumo rodiklių santykiams

Fig 5. The diagram of relative extension of plastic strain along flanges and across middle section of bisteel beam, having different steel strength relations 


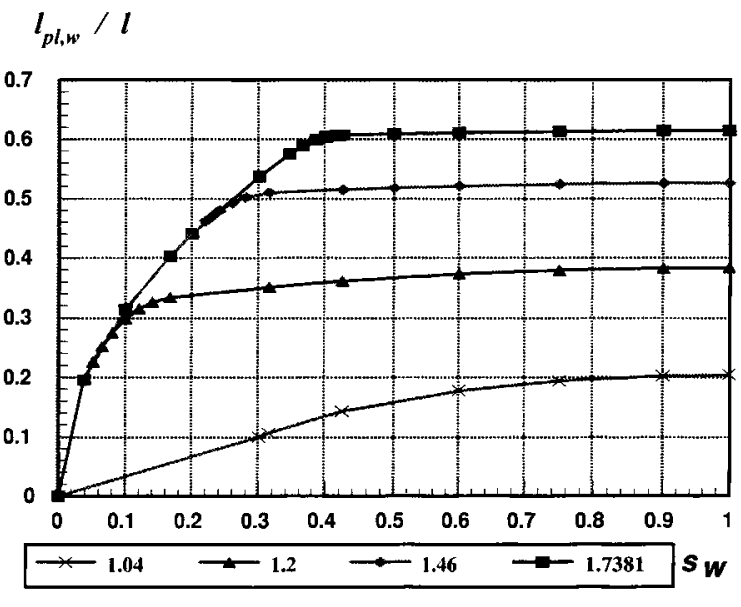

6 pav. Priklausomybès tarp santykinio plastiniu deformacijų išplitimo sijos sienelèje ilgio $l_{p l, w} / l$ ir santykinio maksimaliu plastiniu deformaciju sienelëje gylio $s_{w^{\prime}}=\left(h_{n^{\prime}}-\right.$ $-a) / h_{w}$, esant skirtingiems juostų intarpu ir sijos plieno stiprumo rodikliu santykiams

Fig 6. The diagram of relative extension of plastic strain along web and across middle section of bisteel beam, having different steel strength relations

Plastinio deformavimo metu sijos standumas kinta priklausomai nuo plastinių zonu išplitimo ( 7 pav.). Pradžioje, kol plastinès deformacijos plinta tik sienelejje (esant $\sigma_{y}^{f}>\frac{h}{h_{w}} \sigma_{y}^{w}$ ), ilinkis didèja lètai. Pradèjus tekèti ir juostoms, ilinkių kitimo kreivè ima sparčiai kilti aukštyn ir, juostoms visai tekant (esant ribotoms plastinèms deformacijoms sienelèje), vèl stabilizuojasi.

$$
u / l^{2} \cdot 10^{-2}\left[\mathrm{~m}^{-1}\right]
$$

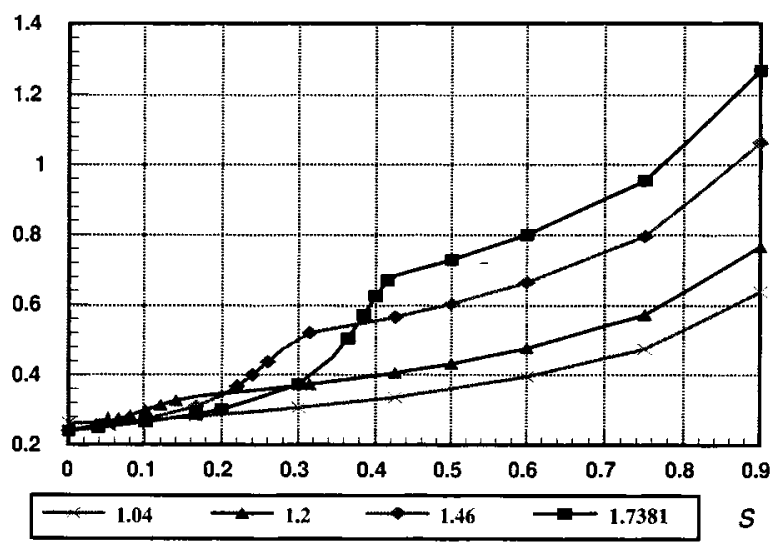

7 pav. Priklausomybès tarp santykinio bimetalès sijos vidurio ilinkio $u / l^{2}$ ir santykinio maksimaliu plastinių deformacijų sienelèje gylio $s=\left(h_{w}-a\right) / h_{w}$, esant skirtingiems juostul intarpu ir sijos plieno stipnumo rodikliu santykiams

Fig 7. The diagram of relative deflection $u / l^{2}$ and relative depth of plastic strain $s=\left(h_{w}-a\right) / h_{w}$ in the middle section of bisteel beams, having different steel strength relations

\section{$p[\mathrm{MN} / \mathrm{m}]$}

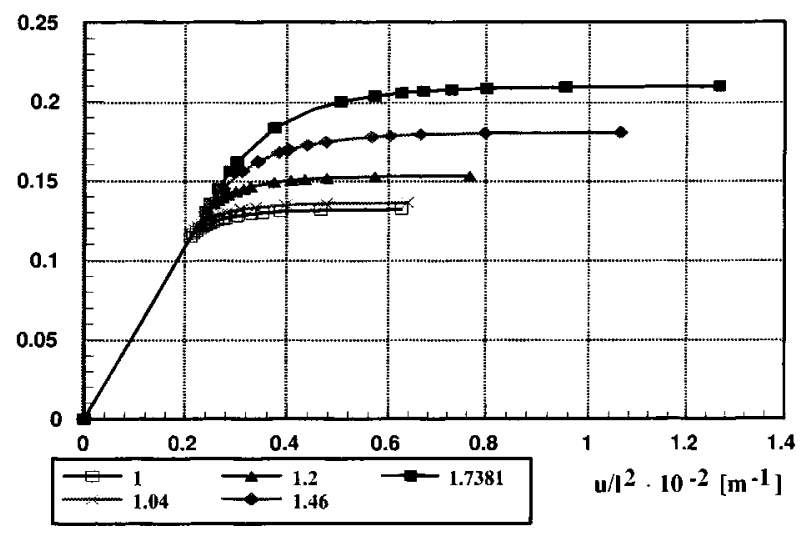

8 pav. Bimetalès sijos deformavimo diagrama, esant skirtingiems juostų intarpų ir sijos plieno stiprumo rodikliu santykiams

Fig 8. Diagram of bisteel beam deformation, having different steel strength relations

Tyrimo metu pasitvirtino žinoma tiesa, kad didèjant sijos juostų intarpu ir sienelès plienų stiprumo rodikliu santykiui gereja sijos stiprumo ir standumo rodikliai (8 pav.).

\section{Modelio tyrimas baigtinių elementų metodu}

Siekiant patikrinti išvestų analizinių išraiškų teisingumą ir nustatyti jų galiojimo ribas, atliktas skaitinis eksperimentas. Tuo tikslu naudotas standartinis baigtinių elementu paketas ANSYS [16]. Tyrimo metu naudotas trimatis dešimties mazgu (su trimis laisvès laipsniais kiekviename mazge) tetraedro formos SOLID-92 tipo baigtinis elementas [17].

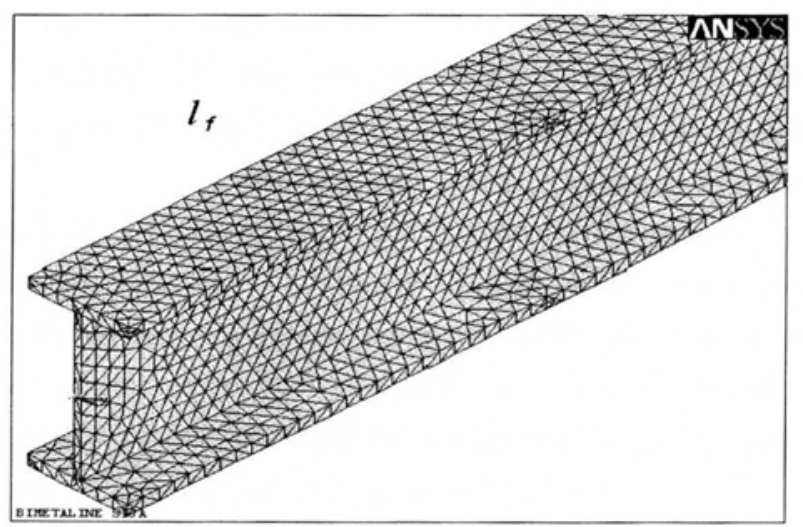

9 pav. Baigtiniu elementų tinklas sijoje

Fig 9. The FEM mesh 
Baigtinių elementų tinklas sijoje pateiktas 9 paveiksle. Išspręsti keli bimetalių sijų pavyzdžiai, esant ivairiems sijos ir juostų intarpu plienų stiprumo rodiklių santykiams $\left(1 \leq \sigma_{y}^{f} / \sigma_{y}^{w} \leq 1,738\right)$ bei plastinių zonụ pasiskirstymams. Dèl 4 skyriuje priimtos sąlygos tai atitinka ir ivairius juostų intarpụ ilgius. Gauti tyrimo rezultatai yra dvejopi. Kai juostų intarpų ilgis santykinai nèra didelis $\left(l_{i n t} / l \leq 0,5\right)$, plastinès deformacijos pirmiausia atsiranda viduriniame sijos pjūvyje ir vẻliau plinta $\mathfrak{i}$ gretimus pjūvius (10 pav.). Taigi plastinio deformavimosi pobūdis sutampa su analizinio tyrimo rezultatais ( 3 pav.).

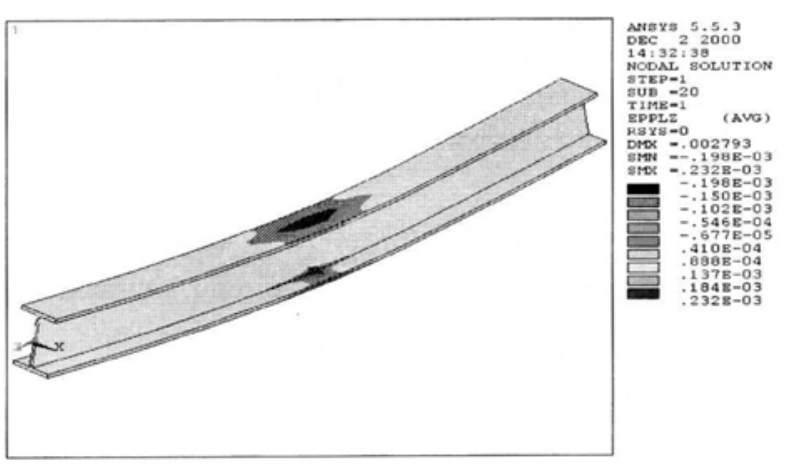

10 pav. Bimetalès sijos su trumpais padidinto stiprumo plieno intarpais juostose $\left(l_{m t} / l \leq 0,6\right)$ deformavimosi pobūdis

Fig 10. The type of plastic deformation of bisteel beam, having short flange insertions $\left(l_{\text {int }} / l \leq 0,6\right)$

Intarpų ilgiui viršijus pusę sijos ilgio, plastinio deformavimo pobūdis pradeda kisti. Toliau ilginant intarpus plastinès deformacijos pirmiau atsiranda ties juostu intarpu sandūromis ( 11 pav.), o vidurinysis sijos pjūvis lieka tamprus. Tuo atveju gaunami skaitinio eksperimento rezultatai labai skiriasi nuo analizinio skaičiavimo rezultatu (vidurio ilinkis $u$ - iki 2,5 karto, o plastiniu zonu pasiskirstymas - iš esmès).

Tiriant išvestų analizinių priklausomybių $(7-10,21)$ pagrịstumą, buvo atliktas sijos vidurio illinkio reikšmių pagal skaitinio eksperimento ir analizinių skaičiavimų rezultatus palyginimas. Rezultatų tapatumas gautas tik esant palyginti nedideliam santykiniam juostų intarpu ilgiui $l_{\text {int }} / l \leq 0,6$. Tai iš esmès patvirtina tai, kad pateiktas analizines išraiškas galima taikyti tampriai plastiškai lenkiamoms bimetalèms suvirintoms dvitèjo skerspjūvio sijoms su padidinto stiprumo plieno intarpais juostose skaičiuoti. Tačiau didèjant santykiniam juostų intarpų ilgiui $l_{\text {int }} / l>0,6$ sparčiai didèja atotrūkis tarp analizinių rezultatu ir reikšmių, gautu naudojant BE paketą ANSYS (12 pav.).

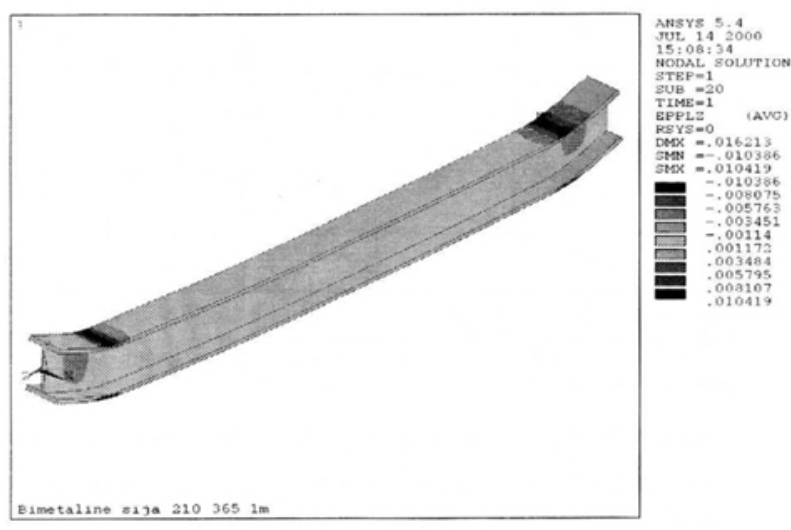

11 pav. Bimetalès sijos su ilgais padidinto stiprumo plieno intarpais juostose $\left(l_{\text {inl }} / l>>0,6\right)$ deformavimosi pobūdis

Fig 11. The type of plastic deformation of bisteel beam, having long flange insertions $\left(l_{i n t} / l \gg 0,6\right)$

Tai galima paaškinti taip: kadangi nagrinejjamu atveju lenkimas sijoje nèra grynasis, dèl skersiniu jègu poveikio skerspjūviuose, be normalinių, atsiranda ir tangentiniai ittempimai. Bendruoju atveju sijose su didele anga ju galima nepaisyti. Tačiau bimetalèse sijose, didinant juostu intarpu ir sijos stiprumo rodiklių santyki

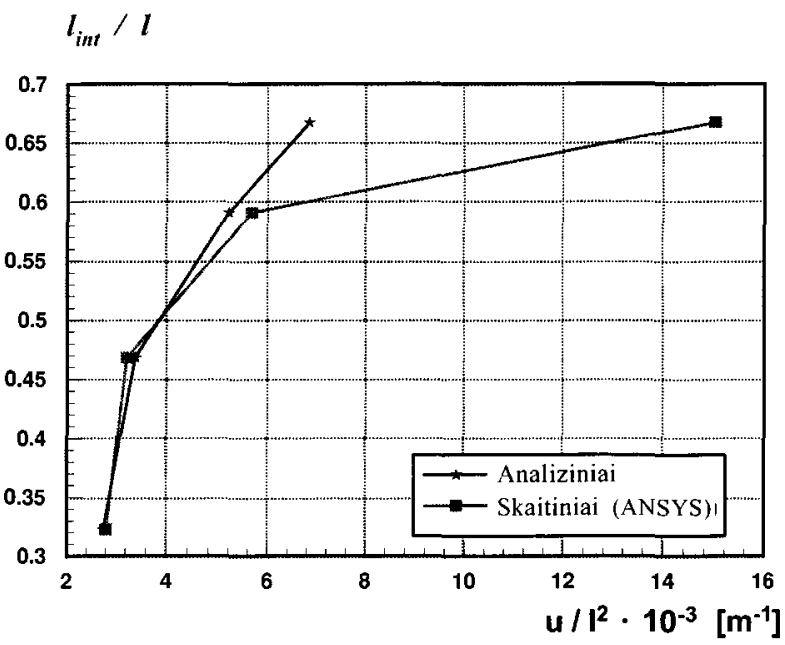

12 pav. Analiziniu ir skaitinių sijos santykinio vidurio ¡linkio $u / l^{2}$ rezultatu priklausomybè nuo santykinio juostu intarpo ilgio $l_{\text {int }} / l$

Fig 12. The diagram of analytical ant experimental results of relative deflection $u / l^{2}$ and relative length of flange insertions $l_{\text {int }} / l$ 
didèja ir juostu intarpų ilgis. Taigi sijos juostų ir jụ intarpu sandūroms artejjant prie atramų, dideja ir skersiniu jẻgu sukeltų tangentinių ittempimų ịtaka sijų standumui (13 pav.), i kurią atliekant analizinius skaičiavimus nebuvo atsižvelgta.

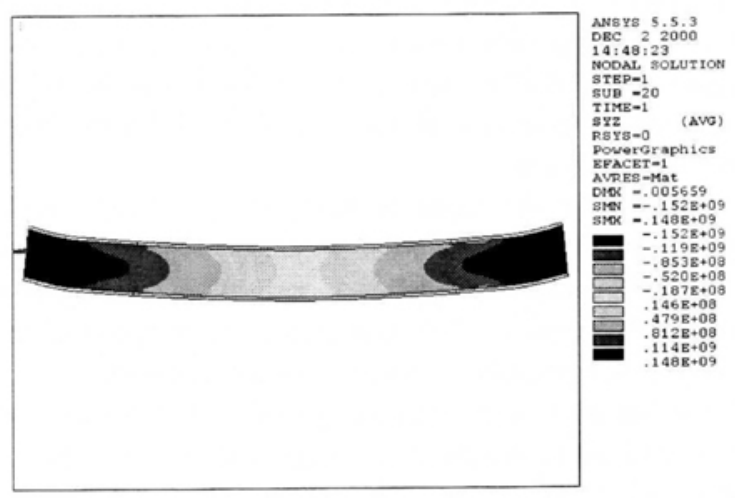

13 pav. Tangentinių itempimų pasiskirstymas bimetalèje dvitejèje sijoje

Fig 13. The distribution of shear stresses in the bisteel beam

Taigi imant tampriosios zonos aukšti pagal išraiškas (11) ir (12) bei vadovaujantis išankstine sąlyga dèl plastinių deformacijų sijos juostų ir jų intarpu suvirinimo siūlèse neleistinumo, juostų intarpu ilgis $l_{\text {int }}$ priklauso nuo plieno stiprumo rodikliu santykio $\sigma_{y}^{f} / \sigma_{y}^{w}$. Jam didejant, ilgeja ir juostų intarpai. Kadangi sparčiai didèjant plastinių deformacijų gyliui jų išplitimas bimetalès sijos sieneleje nèra toks spartus (6 pav.), lemiamas juostų intarpų ilgio veiksnys yra plienų stiprumo rodiklių santykis $\sigma_{y}^{f} / \sigma_{y}^{w}$.

Taigi tampriai plastinio deformavimo metu bimetaliu sijų racionalumas ir ekonomiškumas priklauso nuo juostụ intarpu ir sijos plieno stiprumo rodiklių santykio $\sigma_{y}^{f} / \sigma_{y}^{w}$. Kuo šis santykis didesnis, tuo gaunamas geresnis plienu stiprumo rodikliu išnaudojimas, geresni ir nagrinejjamu sijų standumo rodikliai. Tačiau, taikant ribotụ plastinių deformacijų kriterijų sparčiai ilgèja plastinès zonos juostose. Kartu dideja juostu intarpu ilgis $l_{i n t}$, ir bimetalių sijų skaičiavimui gautos analizinès priklausomybès turi būti patikslintos. Tai laikytina tolesnio tyrimo objektu.

\section{Išvados}

1. Gautos analizinès bimetalių sijų lenkimo momentų skaičiavimo išraiškos gali būti taikomos sijoms, kurių stiprumo skaičiavimas yra atliekamas pagal ribotų plastinių deformacijų kriterijų $(2 \div 4$ bimetaliu siju grupèms [9]). Jos gautos visiems plastinių deformacijų atsivèrimo bei plitimo atvejams ir galioja nepriklausomai nuo sijos apkrovimo ir atrèmimo sąlygų.

2. Gauta analizinè bimetalès sijos vidurio ilinkio skaičiavimo išraiška gali būti taikoma bimetalių sijų standumui tirti. Ji galioja laisvai paremtos sijos, apkrautos išskirstytaja apkrova, atveju.

3. Gautos analizinès plastiniu deformaciju itaka ¡̇vertinančios priklausomybès kiekybiškai aprašo tokius reiškinius:

3.1 proporcingą bimetalių siju laikomosios galios ir standumo didejjimą didejant juostų intarpų plieno stiprumui, sijos plieno stiprumo atžvilgiu;

3.2 plastinių zonų bimetalès dvitejès sijos juostose ir sienelèje ilgiụ skirtumą, didejjantị proporcingai juostu intarpu ir sijos plieno stiprumo rodiklių santykiui;

3.3 spartesni plastinų deformaciju plitimą bimetalių siju juostose nei sienelèje.

4. Gautos analizinès išraiškos naudotinos tolesniems bimetalių dvitèju sijų tyrimams, sprendžiant jų analizès ir optimizavimo uždavinius.

5. Atlikus skaitini eksperimentą BEM paketu ANSYS, gauta:

5.1. Esant riboto ilgio padidinto stiprumo plieno intarpams juostose, kai plastinès zonos atsiveria sijos viduryje, skaitinio eksperimento rezultatai sutapo su analiziniais (gauta paklaida $\leq 8 \%$ galima dèl riboto BE tinklo tankio). Tai iš esmès patvirtina pateiktų analizinių išraiškų taikymą tampriai plastinèms bimetalèms suvirintoms dvitejo skerspjūvio sijoms skaičiuoti.

5.2. Esant juostų intarpo ir sijos ilgio santykiui $l_{f} / l>0,6$ plastinès zonos atsiveria pjūviuose, artimuose atramoms, ir gautos analizinès išraiškos nèra taikytinos.

Skaitinio eksperimento rezultatu nesutapimas su analiziniais, didejant intarpu sijos juostose ilgiui, motyvuojamas didejjančia tangentinių itempimų skerspjūviuose, artimuose atramoms, itaka, kuri išvedant analizines išraiškas nebuvo ivertinta. 


\section{Literatūra}

1. P. J. Dowling, B. A. Burgan. Steel Structures in the New Millennium // Journal of Constructional Steel Research, 1998, Vol 46 (1-3), Paper No 423.

2. A. K. Kvedaras, A. Kudzys, V. Vaitkevičius. Efficient Future Strategies for Constructing with Steel in Lithuania // Journal of Constructional Steel Research, 1998, Vol 46 (1-3), Paper No 19.

3. Е. И. Беленя и др. Металлические конструкции. М.: Стройиздат, 1986. $560 \mathrm{c}$.

4. Е. И. Беленя и др. Металлические конструкции. Спец. курс. М.: Стройиздат, 1982. 472 с.

5. G. W. Owens, P. R. Knowles. Steel Designers' Manual. 5th ed. Oxford, Blackwell Scientific Publlications, 1994. 1266 p.

6. D. A. Fanella, R. Amon, B. Knobloch, A. Mazumder. Steel design for Engineers and Architects. New-York, Van Nostrand Reinhold, 1992. 503 p.

7. Пособие по проектированию стальных конструкций (к СНиП ІІ-23-81*). М.: ЦТИП Госстроя СССР, 1989. $148 \mathrm{c}$.

8. СНиП II-23-81*. Стальные конструкции / Госстрой СССР. М.: ЦТИП Госстроя СССР, 1990. 96 с.

9. В. В. Горев, Б. Ю Уваров, В. В. Филиппов и др. Под ред. В. В. Горева. Металлические конструкции. Т. 1. Элементы стальных конструкций. М.: Высшая школа, 1997. $527 \mathrm{c}$.

10. Н. Л. Чернов, В. С. Шербакин, В. Л. Тарасенко. Прочность изгибаемых элементов при ограниченных пластических деформациях // Совершенствование сварных металлических конструкций / Под ред. М. М. Жербина. Киев: Наукова думка, 1992. 271 с.

11. B. Bresler, T. Y. Lin, J. B. Scalzi. Design of steel structures. 2 nd ed., New York, John Willey \& Sons, Inc, $1968,830 \mathrm{p}$.

12. E. J. Hearn. Mechanics of Material 2. 3th ed. Oxford, Butterworth Heinemann, 1997. 539 p.

13. B. Seely, F. Smith. Advanced Mechanics of Material 2nd ed., New York, John Willey \& Sons, Inc, 1959. 680 p.

14. S. Turskienè. Darbas su sistema MATHEMATICA. Šiauliai: Šiauliu pedagoginis institutas, 1997. $141 \mathrm{p}$.

15. R. Kačianauskas. Computer Methods in Multilevel Modelling of Beams and Shells. Vilnius: Technika, 1995. $395 \mathrm{p}$.

16. ANSYS. Theory Reference. Release 5.4. 1997 SAS IP, Inc. $(C)$

17. ANSYS. Elements Reference. Release 5.4. 1997 SAS IP, Inc. $\mathbb{C}$

Iteikta 20010123

\section{ELASTIC-PLASTIC ANALYSIS OF BISTEEL I-SECTION BEAMS}

\section{A. Jaras, R. Kačianauskas}

Su m m a ry

The elastic-plastic analysis of simple bisteel I-section beam subjected to uniform distributed load (Fig 1) is considered in this paper. The bisteel beam presents a composition of high-strength steel inclusions for the flanges in the region of maximum stresses and of low-strength steel for remaining volume of the beam.

The aim of the paper is development of the explicit analytical model for description of plastic regions with respect to different steel properties as well as to dimensions of high-strength inclusions. The geometrical linear approach and perfectly plastic material model have been assumed.

The variation of the strength ratio of the both steels and the variation of the length of inclusion leads to different distributions of plastic regions in the web and the flanges (Fig 2). By fixing the depth of plastic penetration different explicit expressions (1-10) of the limit bending moment and plastic boundaries (11-18) presented in Fig 3 have been derived. After integration over elastic and plastic regions explicit expressions (19-21) of middle-span deflection have been derived.

Influence of different dimensions and material properties are investigated and presented graphically on Figs $5-8$.

The proposed analytical model has been also tested numerically by the finite element method. The ANSYS code and tetrahedral elements have been used for these purpose (Figs 9-11). A good agreement between the proposed analytical model and numerical experiments has been obtained if the relative length of the high-strength inclusion does not exceed $60 \%\left(l_{\text {inc }} / l \leq 0.6\right)$ (Fig 12). Outside the range of this limit the influence of shear stresses is growing and analytical model has to be corrected by additional terms.

Arūnas JARAS. Research Assistant. Numerical Modelling Laboratory. Vilnius Gediminas Technical University, Sauletekio al. 11, LT-2040 Vilnius, Lithuania.

E-mail: arunas.jaras@st.vtu.lt

A graduate of Civil Engineering Faculty of Vilnius Civil Engineering Institute (1986). Author of 2 papers, 3 reports.

Rimantas KAČIANAUSKAS. Doctor Habil, Professor. Dept of Strength of Materials. Vilnius Gediminas Technical University, Sauletekio al. 11, LT-2040 Vilnius, Lithuania. E-mail: mopror@adm.vtu.lt

PhD (structural mechanics, 1982). Dr Habil (1996). Professor (1997). Scientific visits: University of Stuttgart and Swiss Federal Institute of Technology, Zurich. Author of 1 monograph and over 80 papers. Research interests: computational mechanics, finite element method, computer modelling of structures. 